International Journal of Business Management and Economic Review

Vol. 4, No. 04; 2021

ISSN: 2581-4664

\title{
THE EFFECT OF HEDONIC MOTIVATION, IN STORE DISPLAY, AND PRICE DISCOUNT ON IMPULSE BUYING DECISIONS
}

\author{
Kadek Teja Antariksa and Ni Nyoman Rsi Respati \\ Fakultas Ekonomi dan Bisnis Universitas Udayana, Bali, Indonesia
}

http://doi.org/10.35409/IJBMER.2021.3291

\begin{abstract}
This study aims to determine the effect of hedonic motivation, in store display and price discounts on impulse buying. This research design uses a quantitative approach that can be categorized as associative research when viewed from the variables and their relationships to be studied. The location of this research is in all Miniso outlets in Denpasar City. The population uses all Miniso customers and the sample used is 160 respondents. The data analysis techniques used are Validity Test, Reliability, Classical Assumptions, Multiple Linear Regression, F Test, t Test, and Coefficient of Determination. Based on the results of the study, it can be seen that: (1) hedonic motivation has a significant positive effect on impulse buying, (2) in store display has a significant positive effect on impulse buying, (3) price discount has a significant positive effect on impulse buying. This study is expected to provide an empirical contribution to the relationship between hedonic motivation variables, in store displays, price discounts and impulse buying for the development of marketing science.
\end{abstract}

Keyword: Hedonic Motivation, In Store Display, Price Discount, Impulse Buying.

\section{INTRODUCTION}

Consumptive behavior can be found when shopping, when shopping, consumers often visit shopping centers that offer various needs and attractive promos. One of the patterns of consumer behavior that can be found when in a shopping center is to make purchases spontaneously and unplanned which is referred to as impulse buying or impulse buying (Utami, 2017).

Impulse buying can occur due to the influence of the surrounding environment and also from within a person (Mulianingsih et al, 2019). (Ahmad et al, 2019) stated impulse buying as an act of buying that was not previously recognized consciously as a result of a consideration or purchase intention formed before entering the store. Instant buying tendency is a distinctive characteristic between individuals. So it can be concluded that impulse buying is an unplanned purchase and to buy spontaneously, and there is no consideration so as not to think about the consequences that will be received after buying a product or service.

Factors that become the reason someone is encouraged to do Impulse Buying are internal and external factors. Internal factors in a person are moods that are influenced by emotional states when shopping. While external factors that affect impulse buying are product displays in a store and the shopping environment both inside and outside the store (Ganawati, 2020).

(Herukalpiko, 2013:2) states that the internal factors of Impulse Buying behavior are consumer 


\section{International Journal of Business Management and Economic Review}

Vol. 4, No. 04; 2021

ISSN: 2581-4664

internal cues and consumer personality characteristics, where impulse buying internal stimuli refer to stimuli controlled and carried out by consumers. The internal stimulus in this research is hedonic shopping motivation or Hedonic Motivation. (Lestari, 2015) states that Hedonic Motivation is the emotional behavior of consumers when shopping, consumers really feel something like happy, hate, angry, or feel that shopping is an adventure. Consumers who tend to have a hedonic nature will go shopping when they have free time or when they are having fun (Oktafiana and Indriastuti, 2018).

Research conducted by (Melina and Kadafi, 2017:202) states that In Store Display is to give direction to someone to be interested in observing what actions will create a purchase. Another definition of in-store display put forward by William J. Shultz quoted by (Alma Buchari, 2018:142) is as follows: "Display" means an effort to encourage consumer attention and interest in stores or goods and encourage the desire to buy through direct visual appeal "(direct visual appeal)".

The results of the study (Wilujeng, 2017) state that Price Discount is one of the sales promotion strategies by offering products at lower prices than they should. Price discounts can attract consumers because logically consumers will think that by buying products that have received offers in the form of discounts, they will get a lot of goods by spending a little money, so that is what encourages consumers to make impulse purchases (Gumilang and Nurcahya, 2016) .

With the development of the world economy in the retail business sector, premium brands from countries around the world are becoming more and more popular among consumers, on the other hand, counterfeit goods with low quality enter the market easily, which in turn causes differences in consumer spending patterns.

This research was conducted at the Miniso outlet in Denpasar City, this is because the city of Denpasar has the largest amount of per capita expenditure in Bali so that it contributes to influencing consumptive behavior in the community, as well as pre-surveys that have been carried out by researchers. This prompted the author to examine how the marketing strategy used by Miniso is so that it can attract buyers to make impulse buying (unplanned buyers), which can directly affect the increase in sales.

The reason the researcher conducted this study was considering the differences in the results of previous studies using the same variables. The results of research conducted (Wahyuni \& Rachmawati, 2018) state that hedonic motivation has an influence on impulse buying. Conflicting results found by Rohman (2009) found that hedonic shopping did not affect impulse buying. The results of research conducted by (Saputro, 2019) stated that there was a positive and significant influence of price discounts on impulse buying at minimarket retail consumers in Yogyakarta, but findings (Faisal \& Ikhwan, 2018) which showed that price discounts had no effect on impulse buying at Giant Supermarkets Banjar. Previous research conducted by (Muthiah et al, 2018) explains that the in-store display variable partially has a significant effect on impulsive buying decisions, while research conducted by (Rahmadana, 2016) explains that the product display variable partially has no significant effect on purchasing decisions. impulse buying.

\section{LITERATURE REVIEW AND HYPOTHESES DEVELOPMENT}

Research by Sampurno and Winarso (2015) shows that hedonic motivation has a positive and significant effect on impulse buying. In the research of Amel et al. (2014) revealed that hedonic 


\section{International Journal of Business Management and Economic Review}

Vol. 4, No. 04; 2021

ISSN: 2581-4664

motivation has a significant positive effect on impulse buying. The results of the research by Mulianingsih, et al., (2019) showed that hedonic shopping motivation had a positive and significant effect on the tendency of impulse buying. This is supported by Kosyu et al. (2014), there is a significant direct effect of hedonic motivation on impulse buying. The results of research conducted by Wahyuni \& Rachmawati (2018) state that Hedonic Motivation has an influence on impulse buyin. In the research of Mamuaya and Aditya (2018), it is stated that hedonic motivation has a significant positive effect on impulse buying. Suhartini et al. (2016) the more consumers feel good hedonic motivation, it will cause a higher level of impulse buying. The results of Afif and Purwanto's research, (2020) show that the influence of hedonic shopping motivation, shopping lifestyle, and sales promotion on impulse buying significantly, based on the influence of hedonic shopping motivation, shopping lifestyle and sales promotion on impulsive purchases on Shopee ID consumers the most dominant is hedonic shopping motivation. Conflicting results found by Rohman (2009) found that hedonic shopping did not affect impulse buying.

H1: Hedonic Motivation Affects Impulse Buying

In Store Display is displaying goods sold to make it easier for visitors to choose goods according to their wishes. Sari and Faisal (2018: 51). This is believed to lead to a sense of satisfaction in consumers. . Previous research conducted by Muthiah et al (2018) explains that the in-store display variable partially has a significant effect on impulse buying decisions. Melina \& Kadafi (2018) state that the in-store display variable has a positive and significant effect on impulse buying. This statement is supported by research from Heris, et al (2018: 254) where the results show that the display has a significant effect on impulse buying at the Bang Heris Coffee Shop in Sidoharjo. Research conducted by Agustina Setiyowati and Dwi hastjarja Kustijana (2017) regarding "The Effect of Discount Price, In-Store Display and Sales People on Impulsive Purchases with Impulse Buying Tendency as a Moderate Variable." The results of this test are the discount price and in-store display have a significant effect on impulse buying. The results of the same study were also revealed by I Putu Widya Artana and et al (2019) that in-store displays have a positive effect on impulse buying. Waani and Tumbuan (2015) show that the in-store display variable has a significant partial effect on impulse buying decisions. Conflicting results were put forward by Rahmadana (2016) that the product display variable partially had no significant effect on impulse buying purchasing decisions.

H2: In Store Display Has a Positive Effect on Impulse Buying

\section{METHODS}

This research was conducted in the city of Denpasar, this is because the city of Denpasar has the largest amount of per capita expenditure in Bali. There are three Miniso outlets spread across major malls. The locations are: Miniso Plaza Renon, Miniso Level 21, and Miniso Trans Studio Mart (TSM).

The population in this study are customers who shop at Miniso outlets in Denpasar City whose exact number is unknown (infinite). If the research uses multivariate analysis, the number of sample members is at least 10 times the number of variables to be studied. The number of indicators used in this research is 16 indicators x $10=160$ respondents. So, the respondents needed in this study were 160 respondents.

The analysis technique used in this research is multiple linear regression analysis. Multiple linear 
regression analysis was used to analyze the effect of the independent variables (Hedonic Motivation, In-Store Display, and Price Discount) on the dependent variable, namely Impulse. The mathematical formula of multiple linear regression used in this study is:

Information:

$$
Y=a+\beta_{1} X_{1}+\beta_{2} X_{2}+\beta_{3} X_{3}+\varepsilon
$$

$\mathrm{Y} \quad \quad=$ Impulse Buying

$\beta_{1}, \beta_{2}, \beta_{3} \quad=$ Coefficient Regression

$\mathrm{X}_{1} \quad=$ Hedonic Motivation

$\mathrm{X}_{2} \quad=$ In Store Display

$\mathrm{X}_{3} \quad=$ Price Discount

$\varepsilon \quad=$ error disturbances

\section{RESULT AND DISCUSSION}

Multiple Linear Regression Analysis Results

The analysis used in this study is multiple linear regression analysis. Multiple linear regression analysis was used to analyze the effect of the independent variables (Hedonic Motivation, In Store Display, and Price Discount) on the dependent variable, namely Impulse Buying.

Table 1. Results of Multiple Linear Regression Analysis

\begin{tabular}{|c|c|c|c|c|c|}
\hline \multirow[t]{2}{*}{ Model } & \multicolumn{2}{|c|}{$\begin{array}{l}\text { Unstandardized } \\
\text { Coefficients }\end{array}$} & \multirow{2}{*}{$\begin{array}{l}\text { Standardized } \\
\text { Coefficients } \\
\text { Beta }\end{array}$} & \multirow[b]{2}{*}{$\mathrm{T}$} & \multirow[b]{2}{*}{ Sig. } \\
\hline & $\bar{B}$ & Std. Error & & & \\
\hline $\begin{array}{ll}1 & \text { (Constant) }\end{array}$ & 4,485 & 1,152 & & 3,895 & 0,000 \\
\hline Hedonic motivation $\left(\mathrm{X}_{1}\right)$ & 0,385 & 0,057 & 0,455 & 6,729 & 0,000 \\
\hline In store display $\left(\mathrm{X}_{2}\right)$ & 0,277 & 0,097 & 0,190 & 2,861 & 0,005 \\
\hline Price discount $\left(\mathrm{X}_{3}\right)$ & 0,374 & 0,100 & 0,239 & 3,757 & 0,000 \\
\hline $\mathrm{R}$ & 0,720 & & & & \\
\hline R Square & 0,519 & & & & \\
\hline Adjusted R Square & 0,510 & & & & \\
\hline F Statistic & 56,085 & & & & \\
\hline F Sig. & 0,000 & & & & \\
\hline
\end{tabular}

Primary Data, 2021

Based on Table 1 above, the regression equation can be arranged as follows:

$\mathrm{Y}=4,485+0,385 \mathrm{X}_{1}+0,277 \mathrm{X}_{2}+0,374 \mathrm{X}_{3}$

\section{The Effect of Hedonic Motivation on Impulse Buying}

Based on the results of hedonic motivation analysis on impulse buying, a significance value of 0.000 was obtained with a t-count value of 6.729 . The significance value is $0.000<0.05$ and the $t$ count value is $6.729>\mathrm{t}$ table 1.975 indicates that $\mathrm{H} 0$ is rejected and $\mathrm{H} 1$ is accepted. The results in this study mean that hedonic motivation has a positive and significant effect on impulse buying. This shows that the higher the consumer's hedonic motivation, the higher the impulse buying at Miniso. Hedonic motivation is shopping because it gets fun and feels that shopping is 


\section{International Journal of Business Management and Economic Review}

Vol. 4, No. 04; 2021

ISSN: 2581-4664

interesting. One of the motivations for shopping is getting information (Utami, 2017). Priambada (2018) Hedonic motivation is defined as an overall assessment of the benefits of experience and sacrifice, for entertainment and escape. Hedonic motivation is the motivation that exists within a person based on pleasure, emotional value, and entertainment based on momentary pleasure that causes direct impulses from within. The hedonic lifestyle will encourage consumers to shop spontaneously at Miniso.

These results indicate that the values contained in hedonic motivation have a significant impact on impulse buying at Miniso. Hedonic motivation measured by indicators: relieve stress, consumers prefer to shop for others than for themselves, consumers prefer to look for shopping places that offer discounts and low prices, enjoyment in shopping will be created when they spend time together with family or friends and consumers shopping to follow the trend of new models proven to be able to increase impulse buying at Miniso. The results of this study indicate that with the hedonic lifestyle of consumers, it will increase impulse buying

The results of this study are in accordance with previous research conducted by Sampurno and Winarso (2015) that hedonic motivation has a positive and significant effect on impulse buying. In the research of Amel et al. (2014) revealed that hedonic motivation has a significant positive effect on impulse buying. The results of the research by Mulianingsih et al. (2019) showed that the hedonic shopping motivation consisting of adventure shopping, value shopping, idea shopping, social shopping, and relaxation shopping simultaneously had a positive and significant effect on the tendency of impulsive buying, then partially, adventure shopping. , idea shopping and relaxation shopping have a positive and significant effect on the tendency of impulse buying. This is supported by Kosyu et al. (2014), there is a significant direct effect of hedonic motivation on impulse buying. The results of research conducted by Wahyuni \& Rachmawati (2018) state that Hedonic Motivation has an influence on impulse buyin. In the research of Mamuaya and Aditya (2018), it is stated that hedonic motivation has a significant positive effect on impulse buying. Suhartini et al. (2016) the more consumers feel good hedonic motivation, it will cause a higher level of impulse buying. The results of Afif and Purwanto's research, (2020) show that the influence of hedonic shopping motivation, shopping lifestyle, and sales promotion on impulse buying significantly, based on the influence of hedonic shopping motivation, shopping lifestyle and sales promotion on impulsive purchases on Shopee ID consumers the most dominant is hedonic shopping motivation.

The Effect of in Store Display on Impulse Buying

Based on the results of the in-store display analysis on impulse buying, a significance value of 0.005 was obtained with a t-count value of 2.861 . The significance value is $0.005<0.05$ and the $t$ count value is $2.861>\mathrm{t}$ table 1.975 indicates that $\mathrm{H} 0$ is rejected and $\mathrm{H} 2$ is accepted. The results in this study mean that in-store display has a positive and significant effect on impulse buying. This shows that the better the in-store display, the more impulse buying at Miniso. In-store display is an attribute or display designed to give an attractive impression to the product. Attractive in-store displays can be encouraging. consumers to make unplanned purchases (impulse buying) (Purnomo, 2011). According to Foster (2008: 72) In-Store Display is an effort to encourage consumer attention and interest in stores or goods and encourage the desire to buy through direct visual appeal or commonly called direct visual appeal. A neat and attractive appearance in the store will bring up the consumer's desire to make purchases without being planned in advance. 


\section{International Journal of Business Management and Economic Review}

Vol. 4, No. 04; 2021

ISSN: 2581-4664

These results indicate that the values contained in the in-store display have a significant impact on impulse buying at Miniso. In store displays measured by indicators: always make the right purchases, buy products that are in the product arrangement and try interesting new products on display proven to be able to increase impulse buying on Miniso, The results of this study indicate if Miniso is able to make an in-store display that is neat and attractive it will increase impulse buying.

The results of this study are in accordance with previous research conducted by Muthiah et al (2018) explaining that the in-store display variable partially has a significant effect on impulse buying decisions. Melina \& Kadafi (2018) state that the in-store display variable has a positive and significant effect on impulse buying. This statement is supported by research from Heris, et al (2018: 254) where the results show that the display has a significant effect on impulse buying at the Bang Heris Coffee Shop in Sidoharjo. Research conducted by Agustina setiyowati and Dwi hastjarja kustijana (2017) regarding "The Effect of Discount Price, In-Store Display and Sales People on Impulsive Purchases with Impulse Buying Tendency as a Moderate Variable." The results of this test are the discount price and in-store display have a significant effect on impulse buying. The results of the same study were also revealed by I Putu Widya Artana and et al (2019) that in-store displays have a positive effect on impulse buying. Waani and Tumbuan (2015) show that the in-store display variable has a significant partial effect on impulse buying decisions.

The Effect of Price Discount on Impulse Buying

Based on the analysis of the price discount on impulse buying, a significance value of 0.000 was obtained with a $t$-count value of 3.757. The significance value is $0.000<0.05$ and the $t$-count value is $3.757>\mathrm{t}$-table 1.975 indicates that $\mathrm{H} 0$ is rejected and $\mathrm{H} 3$ is accepted. The results in this study mean that the price discount has a positive and significant effect on impulse buying. This shows that the higher the discount given, the more impulse buying at Miniso. Waani and Tumbuan (2015) define that price discount is a decrease in the price of several products in a certain period. According to Ben Lowe (2010) in Lestari (2016), price discounts are a form of sales promotion that is often applied by marketers which is aimed at the final consumer. Devita (2018) price discount is a reduction in the price of a product from the normal price within a certain period. Wilujeng 2017 also said that the promotion of discounted prices provided benefits. The provision of discounted prices will encourage consumers to make purchases spontaneously at Miniso.

These results indicate that the values contained in the discount price have a significant impact on impulse buying at Miniso. Hedonic motivation as measured by indicators: can trigger consumers to buy in more quantities, anticipate competitor promotions and support trade in larger quantities proven to be able to increase impulse buying at Miniso. The results of this study indicate that if Miniso is able to increase price discounts, it will increase impulse buying. .

The results of this study are in accordance with previous research conducted by Saputro (2019) which stated that there was a positive and significant effect of price discounts on impulse buying for minimarket retail consumers in Yogyakarta and research by Celine.M. Wonggo (2020) showed that the price discount variable had an effect on positive on impulse buying in department store purchases. It is the same with research conducted by Gumilang and Nurcahya (2016), Melina and Kadafi (2017) state that price discounts have a positive and significant effect on impulse buying. This research is also supported by research conducted by Setyaningrum et al. 


\section{International Journal of Business Management and Economic Review}

Vol. 4, No. 04; 2021

ISSN: 2581-4664

(2016), Suhiryanto et al. (2018) which also states that the price discount has a significant positive effect on impulse buying. The results of research by Rahmidani (2021) and Ninik Rumiati (2021) stated that the price discount had a significant and positive effect on impulse buying.

\section{F Test Results}

Based on the results of the regression analysis in Table 1, the independent variables have a simultaneous (simultaneous) effect on the dependent variable. The results of the F test which were analyzed using the SPSS program obtained the calculated $\mathrm{F}$ value of $56.085>\mathrm{F}$ table 2.66 and a significance of $0.000<0.05$. This result means that there is a significant influence between hedonic motivation, in-store display and price discount on impulse buying. Thus, the model is considered worthy of testing and proving the hypothesis can be continued.

Coefficient of Determination Test Results $\left(\mathrm{R}^{2}\right)$

Based on Table 1, the Adjust $\mathrm{R}$ Square value is 0.510 , this means that 51 percent of the variation in impulse buying $(\mathrm{Y})$ is influenced by the hedonic motivation variable (X1), in store display (X2) and price discount (X3), the rest is $(100 \%-51 \%)=49$ percent influenced by other factors outside the model.

\section{CONCLUSION}

Based on the research that has been done, it can be seen that theoretically, this research as a whole supports several pre-existing theories. This study is expected to provide an empirical contribution to the relationship between hedonic motivation variables, in store displays, price discounts and impulse buying for the development of marketing science.

Data processing was carried out by using regression analysis techniques to estimate the causal relationship between predetermined variables. This study also uses regression analysis, $\mathrm{F}$ test, $\mathrm{t}$ test and Coefficient of Determination to test the strength of the direct influence of hedonic motivation variables (X1), in store display (X2) and price discount (X3) on impulse buying (Y). The results of this study are expected to be used to enrich references and knowledge related to hedonic motivation variables, in store displays, price discounts and impulse buying.

The results of this study are expected to be an additional reference and to strengthen the results of studies related to the influence of hedonic motivation variables, in store displays and price discounts on impulse buying.

\section{REFERENCES}

A.T. Kearney (2017). Indonesia Masuk Daftar 10 Pasar Ritel Teraktraktif. Katadata Indonesia. Diambil dari: http://databoks.katadata.co.id/data

Agustina setiyowati dan Dwi hastjarja kustijana (2017) , "Pengaruh Discount Price, In-Store Display dan Sales People Terhadap Pembelian Impulsif dengan Impulse Buying Tendency sebagai Variable Moderat", (J-MKLI Vl. 1, No. 1, April 2017),

Ahmad, M., Ali, H., Malik, M., Humayun, A., \& Ahmad, S. 2019. Factors Affecting Bagyarta, S. D., \& Dharmayanti, D. 2014. Analisa Pengaruh Hedonic dan Utilitarian Value terhadap Repurchase Intention pada Industri Pusat Kebugaran Kelas Menengah Atas di Sidoarjo. Jurnal Manajemen Pemasaran Petra,

Afif, M. dan Purwanto. (2020). Pengaruh Motivasi Belanja Hedonis, Gaya Hidup Berbelanja dan Promosi Penjualan terhadap pembelian Impulsif pada Konsumen Shopee ID. Jurnal Aplikasi 


\section{International Journal of Business Management and Economic Review}

Vol. 4, No. 04; 2021

ISSN: 2581-4664

Manajemen dan Inovasi Bisnis STIE Kertanegara Malang

Alfisyahrin S. Priambada. 2018."Pengaruh Hedonic Motives terhadap Shopping Lifestyle dan Impulse Buying.”. Jurnal Administrasi Bisnis. 2018 Jul;60(01).

Alma, Buchari. (2018). Manajemen Pemasaran Dan Pemasaran Jasa. Bandung: Penerbit Alfabet.

Amanah, Dita dan Stephany P. Pelawi. (2015). Pengaruh Promosi Penjualan (Sales Promotion) dan Belanja Hedonis (Hedonic Shopping) Terhadap Impulsive Buying Produk Matahari Plaza Medan Fair. Vol.III No.02 Jurnal Quanomic.

Amel, G., Maachou, D.E.K., dan Elyas, S. (2014). Exploring women motivations toward Impulse Buying behavior in Algeria. Romanian Journal of Marketing. Vol. 2, No. 1, pp. 30-37.

Andryansyah, M. and Arifin, Z., (2018). Pengaruh hedonic motives terhadap Shopping Lifestyle dan Impulse Buying (Survei pada Konsumen Hypermart Malang Town Square yang melakukan pembelian tidak terencana). Jurnal Administrasi Bisnis, Vol. 57, No. 1, pp. 111-118.

Arifah, Fildzah Qisthina, and Marheni Eka Saputri. "Pengaruh Visual Merchandising Terhadap Impulse Buying." SOSIOHUMANITAS 20, no. 1 (2018).

Ariyanti, F. (2017). Toko Ritel Tutup, karena Daya Beli atau Digitalisasi. Retrieved October 15, 2018, from Liputan6: https://www.liputan6.com/bisni s/read/3142860/toko-riteltutup-karenadaya-beli-ataudigitalisasi

Badan Pusat Statistik (2019). Rata-rata Konsumsi Per Kapita Sebulan Provinsi Bali Menurut Kabupaten/Kota, 1997-2018. Jakarta: BPS RI. Diambil pada https://bali.bps.go.id/dynamictable/2016/01/25/7/rat a-rata- konsumsi-per-kapita-sebulanprovinsi-balimenurut-kabupaten-kota-1997-2018.html. Diakses pada tanggal 17 Agustus 2020.

Barata, Dion Dewa and Agatha Febriyanti Napitupulu, (2019), - Why We Switch from Conventional to Sharia Bank?\| in International Conference on Economics, Management, and Accounting, KnE Social Sciences, pages 160-174. DOI 10.18502/kss.v3i26.537

Belch, G. E. \& Belch, M. A. (2009). Advertising and Promotion: An Integrated Marketing Communication Perspective. 8th Edition. New York: Pearson Education

CNBC Indonesia (2020) PO, Miniso Raup USD 608juta https://www.cnbcindonesia.com/market/20190507112851-17 70931/kenaikan-penjualan-ritelmaret-2019-tertinggi-dalam-3-tahun. Akses: 20 November 2020]

Celline M.Wonggo (2020) Dampak Discount,Brand Image, dan Instore Display Terhadap Impulse Buying pada PT.Matahari Departemen Store Mantos 2.

Desman, F.N., Yulihar, M., dan Zeshasina, R. (2018). Pengaruh Gaya Hidup, Store Atmosphere, Dan Motivasi Hedonis Terhadap Imuplsive Buying Konsumen May17 Distro Padang. E-jurnal Bunghatta. Vol. 9, No. 2, pp. 1-15.

Devid Ulva, Sari (2017). "Pengaruh Price Discount, Sales Promotion dan InStore Display Terhadap Keputusan Impulse Buying pada PT Matahari Departement Store Tbk Panakkukang Makassar" Universitas Islam Negeri Alauddin Makassar.

Dwijayanto, Andi \& Rafael, Eldo Christoffel (2018, 4 Januari). Peritel asing ekspansif masuk 


\section{International Journal of Business Management and Economic Review}

Vol. 4, No. 04; 2021

ISSN: 2581-4664

pasar ritel lokal. Kontan.co.id [Online]. Diambil dari: http://m.kontan.co.id/news/peritel asing-ekspansif-masuk-pasarritel-lokal. [Akses: 20 November 2019]

Faisal, Della Ruslimah Sari dan Ikhwan. 2018. "Pengaruh Price diskon, Bonus Pack dan In-store Display terhadap keputusan Impulse Buying pada Giant Ekstra Banjar." Jurnal Sains Manajemen dan Kewirausahaan vol.2 no. 1.

Foster, Bob (2008). "Manajemen Ritel". Bandung: Alfabeta.

Ganawati, N., Sudarmini, K., \& Sariani, N. K. (2020). Faktor Eksternal Dan Internal Yang Mempengaruhi Impulse Buying Pembeli Pada Toko Ritel Waralaba Di Kabupaten Gianyar. WACANA EKONOMI (Jurnal Ekonomi, Bisnis dan Akuntansi), 18(1), 33-40.

Ghozali, Imam, 2016. Aplikasi Analisis Multivariate dengan program IBM SPSS 19”, Edisi 5 Cetakan V, Badan Penerbit Universitas Diponegoro, Semarang.

Gumilang, Wayan Aris Dan Nurcahya, I Ketut. 2016. Pengaruh Price Discount Dan Store Atmosphere Terhadap Emotional Shopping Dan Impulse Buying. E-Jurnal Manajemen Unud, 15 (3), pp. 1859-1888.

Heris Rano, Saputra, Ennydan Siti Rosyafah. (2018). "Pengaruh Store Atmosphere, Harga, Display dan Kualitas Pelayanan terhadap Kepuasan Konsumen pada Coffee Shop Bang Heris di Sidoharjp." Jurnal Branchmarck, vol 4 issue 1.

Herukalpiko, Diah Kenanga Dwirani, Apriatni Endang Prihatini, dan Widayanto. 2013. Pengaruh Kebijakan Harga, Atmosfer Toko, Dan Pelayanan Toko Terhadap Perilaku Impulse Buying Konsumen Robinson Departement Store Semarang. Journal Of Social And Politic Of Science, pp: $1-9$

Hidayat, Agung (2017, Mei 22). Miniso agresif menambah toko di Indonesia. Kontan.co.id [Online]. Diambil dari: http://m.kontan.co.id/news/Miniso -agresif-menambah-toko- Hidup Berbelanja, Dan Karyawan Toko Terhadap Pembelian Impulsif Pada Pengunjung Hermes Palace Mall Kota Banda Aceh. Jurnal Ilmiah Mahasiswa Ekonomi Manajemen, Vol.2, No.3, pp. 108125

I Putu Widya Artana, dkk (2019), "Pengaruh Store Atmosphere,Display Product dan Price Discount Terhadap Impulse Buying” Studi Kasus pada Indomaret di kota Denpasar, E-jurnal Ekonomi dan Bisnis Universitas Udayana 8.4, 2019, 376

Imbayani, I. G. A., \& Novarini, N. N. A. (2018). Pengaruh Shopping Lifestyle,Fashion Involvement Dan Positive Emotion Terhadap Impulse Buying Behavior. Jurnal Ilmiah Manajemen \& Bisnis, 3(2), 199-210.

Japarianto, Edwin dan Sugiharto, Sugiono. 2011. Pengaruh Shopping Life Style Dan Fashion involvement terhadap Impulse Buying Behavior Masyarakat HighIncome Surabaya. Jurnal Manajemen Pemasaran, 6(1), h. 32-41

Junita, N. D. S. 2018. Pengaruh Gaya Hidup Hedonis, Keterlibatan Mode Dan Lingkungan Di Dalam Toko Terhadap Pembelian Impulsif (Studi Pada Konsumen Toko COLORBOX di Mall Boemi Kedaton Bandar Lampung). Skripsi. Lampung: Fakultas Ilmu Sosial Dan Ilmu Politik Universitas Lampung.

Kontan (2017). Miniso agresif menambah toko di Indonesia. https://www.kontan.co.id/. 10 oktober 2020

Kosyu, D.A., Kadarisman, H., Yusri, Abdillah. (2014). Pengaruh Hedonic Shopping Motives Terhadap Shopping Lifestyle dan Impulse Buying (Survei pada Pelanggan Outlet Stradivarius di Galaxy Mall Surabaya). Jurnal Administrasi Bisnis. Vol.14, No.2, pp. 1-7.. 


\section{International Journal of Business Management and Economic Review}

Vol. 4, No. 04; 2021

ISSN: 2581-4664

Kuncoro, M. 2013. Metode Riset untuk Bisnis \& Ekonomi: Bagaimana Meneliti dan Menulis Tesis? Jakarta: Penerbit Erlangga.

Lestari, I.P. (2015). Pengaruh Hedonic Shopping Motivation Terhadap Impulse Buying Melalui Positive Emotion Customer Flashyshop. Jurnal Ilmu \& Riset Manajemen, Vol. 3, No.7, pp. 1-17. Mamuaya, N.I., dan Aditya, P. (2018). The Influence Of Sales Promotion And Store Atmosphere On Hedonic Shopping Motivation And Consumer Impulse Buying In The Hypermart Of Manado City North Sulawesi.

Melina, \& Kadafi. (2018). Pengaruh price discount dan in-store display terhadap impul sebuying forum ekonomi ISSN Online: 2528-150X 201, 19(2), 201-209.

MINISO (2018). Brand Profile, Brand Origin, Brand Philosophy, Brand Life, dan Product. MINISO Japan. Diambil dari: http://miniso.co.id/getinfo.php?to p=1. (Akses : 20 November 2019 \& 21 November 2019)

Mulianingsih, D., DH, A. F., \& Alfisyahr, R. (2019). Pengaruh Motivasi Belanja Hedonis Terhadap Kecenderungan Pembelian Impulsif di Online Shop (Survei Online pada Konsumen Zalora Indonesia di Kota Surabaya). Jurnal Administrasi Bisnis, 66(1), 56-6

Muthiah, I., Parawansa, D. A. ., \& Munir, A. R. (2018). Pengaruh Visual Merchandising , In Store Display , Dan Store Atmosphere Terhadap Perilaku Impulse Buying ( Studi Kasus: Konsumen Matahari Department Store Di Kota Makassar) the Effect of Visual Merchandising , Product Display Dan Store Atmosphere on Impu. Hasanuddin Journal of Applied Business and Entrepreneurship, 1, 88-103.

Ninik Rumiati, Ninik Rumiati. Pengaruh Hedonic Shopping Motivation dan Price Discount terhadap Impulse Buying pada E-Commerce Shopee. Diss. Universitas Teknologi Yogyakarta, 2021.

Oktafiana, S. dan Indriastuti, H. (2018). Membangun motivasi hedonic shopping dan store atmosphere terhadap Impulse Buying pada konsumen matahari departement store mall plaza mulia samarinda. In Prosiding SNMEB (Seminar Nasional Manajemen dan Ekonomi Bisnis). Vol. 1, pp. 414-421. Operasional Bisnis Ritel Modern di Indonesia. Jakarta: Salemba Empat.pada Swalayan Sami Luwes Surakarta). Skripsi, Universitas Sebelas Maret Surakarta.

Purnomo, H., dan Riani, L.P. (2018). Analisis Hedonic Shopping Motives Terhadap Impulse Buying Toko Daring pada Masyarakat Kota Kediri. Ekspektra: Jurnal Bisnis dan Manajemen. Vol. 2, No.1, pp. 68- 88.

Putra, Nobel I., Pangestu, Edriana., dan Devita, Lusi DR. 2018. Pengaruh Diskon dan Pemberian Hadiah Terhadap Pembelian Implusif Pada Fashion Retail. Jurnal Administrasi Bisnis. Vol 6 No. 4

Rahmidani, Rose (2021) . "Pengaruh Store Atmosphere Dan Price Discount Terhadap Impulse Buying Dengan Positive Emotion Sebagai Variabel Intervening Pada Produk Fashion." Jurnal Ecogen 4.1 (2021): 644-658.

Rahmadana, N. M. S. (2016). Pengaruh Display Produk dan Suasana Toko Terhadap Pembelian Impulsif di Minimarket Eramart Cabang Lembuswana Samarinda. EJournal Ilmu Administrasi Bisnis, 4(3), 683-697.

Rahyuda Ketut Utari, Made Dwi, I., and I. Gusti Ayu Ketut Giantari (2017) "Pengaruh Kepribadian Merek Terhadap Komitmen dan Kepercayaan Merek, Serta Dampaknya Terhadap Loyalitas Merek." Matrik: Jurnal Manajemen, Strategi Bisnis dan Kewirausahaan (2017).

Rohman, F. (2009). Peran Nilai Hedonik Konsumsi dan Reaksi Impulsif sebagai Mediasi 


\section{International Journal of Business Management and Economic Review}

Vol. 4, No. 04; 2021

ISSN: 2581-4664

Pengaruh Faktor Situasional terhadap Keputusan Pembelian Impulsif di Butik Kota Malang. Jurnal Aplikasi Manajemen. Vol. 7, No. 2, pp. 251-261.

Saputro, I. B. (2019). Pengaruh Price Discount Dan Store Atmosphere Terhadap Impulse Buying Dengan Positive Emotion Sebagai Variabel Mediasi Pada Konsumen Ritel Minimarket Kota Yogyakarta. Jurnal Ilmu Manajemen Uninversitas Negeri Yogyakarta, 16, 35-47.

Sari, D.A.T. dan Alit, Suryani. (2014). Pengaruh Merchandising, Promosi Dan Atmosfir Toko Terhadap Impulse Buying . Jurnal Manjemen. Vol. 3, No. 4, pp. 851-867.

Sampurno, T.P dan Winarso. (2015). Pengaruh Motivasi Hedonis, Browsing, dan Gaya Belanja terhadap Pembelian Produk Fashion pada Online Shop (Pada Mahasiswa Universitas Muhammadiyah Yogyakarta). Jurnal Manajemen dan Ekonomi Universitas Muhammadiyah Yogyakarta

Setyaningrum, Febe Yustina, Zainul Arifin, Dan Edy Yulianto. 2016. Pengaruh Hedonic Motives Terhadap Shopping Lifestyle Dan Impulse Buying (Survei Pada Konsumen Superindo Supermarket Yang Melakukan Impulse Buying). Jurnal Administrasi Bisnis. 7 (1).

Sugiyono. 2018. Metode Penelitian Kuantitatif, Kualitatif, dan R\&D. Bandung: Alfabeta

Suhartini, Y.I., Rodhiyah, R. dan Listyorini, S. (2016). Pengaruh Shopping Lifetyle, Fashion Involvement, dan Hedonic Shopping Motivation Terhadap Impulse Buying . Jurnal Ilmu Administrasi Bisnis. Vol. 5, No.1, pp.1-10.

Suharyono (2017). Perilaku Konsumsi Dalam Menggunakan Smartphone Ditinjau Dari Perspektif Ekonomi Islam (Studi Kasus Pada Mahasiswa Jurusan Ekonomi Islam IAIN Bengkulu). skripsi, program studi ekonomi syariah jurusan ekonomi islam fakultas syariah dan ekonomi islam lain bengkulu. 2017.

Suhriyanto, Rois Arifin, Dan Afi Rachmat Slame. Pengaruh Shopping Lifestyle, Discount Dan Fashion Involvement Terhadap Impulse Buying Pada Mahasiswa Pengunjung Matos. Jurnal Ilmiah Riset Manajemen. 7 (7).

Syazkia, S. N., Yuliati, A. L. (2018). The Effect of Bonus Pack and Price Discount on Impulse. eProceedings of Management, 5(2), 2561-2568.

Tjantoko, L.E. (2015). Analisa Pengaruh Promosi dan Hedonic Motivation Terhadap Impulse Buying di Ron's Laboratory Galaxy Mall Surabaya. Jurnal Strategi Pemasaran, Vol. 3, No.1, pp.1-7. Utami, Christina W. (2010). Manajemen Ritel, Strategi dan Implementasi

Top Brand. 2020. Top Brand Index Fase 2 Pada Kategori Top Brand Index 2020. https://www.topbrand-award.com/top-brand-indexl. (25 Agustus 2020).

Tribun, Bisnis 2017, Tahun ini Miniso Bakal Tambah 110 Gerai Baru, Diakses pada 03 November 2020, dari https://www.tribunnews.com

Utami, C. W. 2017. Manajemen Ritel : Strategi Dan Implementasi Operasional Bisnis Ritel Modern Di Indonesia. Jakarta Selatan: Salemba Empat.

Vinci, M. (2009). Manajemen Bisnis Eceran. Bandung: Sinar Baru Algensindo.

Waani, R. C., \& Tumbuan, W. J. 2015. The Influence Of Price Discount, Bonus Pack, And in Store Display On Impulse Buying Decision In Hypermart Kairagi Manado. Jurnal Riset Ekonomi, Manajemen, Bisnis Dan Akuntansi, 3(3).

Wahyuni, D. F., \& Rachmawati, I. (2018). Hedonic Shopping Motivation Terhadap Impulse Buying. Jurnal Riset Bisnis Dan Manajemen, 11(2), 9. https://doi.org/10.23969/jrbm.v11i2.701

Wahyuni, R. S., \& Setyawati, H. A. (2020). Pengaruh Sales Promotion , Hedonic Shopping Motivation dan Shopping Lifestyle Terhadap Impulse Buying pada E-Commerce Shopee. 
International Journal of Business Management and Economic Review

Vol. 4, No. 04; 2021

ISSN: 2581-4664

2(April), 144-154.

Wiguna, A.A.I.N., dan Nurcaya, I.N. (2013). Pengaruh Fashion Involvement, In store display dan Kewajaran Harga terhadap Impulse Buying . Bali. Jurnal fakultas Ekonomi dan Bisnis Universitas Udayana. Vol. 3, No. 12, pp. 3695-370

Wilujeng, S. (2017). Pengaruh Price Discount Dan Bonus Pack Terhadap Impulse Buying Konsumen Indomaret di Kecamatan Sukun Kota Malang. Journal FEB Universitas Kanjuruhan Malang, 457-469.

Yistiani, N.N.M., Yasa, N.N.K., dan Suasana. 2012. Pengaruh Atmosfer GeraI dan Pelayanan Ritel Terhadap Nilai Hedonik dan Pembelian Impulsif. Denpasar: Jurnal Management, Strategi Bisnis dan Kewirausahaan

Yuniarti, Rozmita Dewi dan Aprianti, Ridwan Subhi. 2009. "Pengaruh In Store Display Terhadap Keputusan Pembelian Minuman Berkarbonasi Coca-Cola (Survei Pada Konsumen Di Carrefour Paris Van Java Sukajadi Bandung)". E-Journal Pendidikan Manajemen Bisnis, Strategic, Volume 8, Nomor 15, Februari 2009 